\title{
Three Poems about Love's Inner Modes
}

\author{
TRANSLATOR'S NOTE AND TEXT
}

These three standalone Tamil Sangam poems are taken from the following classical anthologies: The Short Collection (Kuruntokai), Excellent Landscapes (Narrinai), and Four Hundred in the Inner Mode (Akanānūiru). The first manages to evoke in a few lines the all-too familiar feeling that at least one of the lovers is never in the right place at the right time. In the second, we have a somewhat surprising farewell scene: the man is on the verge of leaving his beloved behind as he sets off in order to seek his fortune. Things don't quite work out as he had planned. The last poem, a longer statement like others in Four Hundred in the Inner Mode, brings the man's not-so-secret lover, a courtesan, into contact with his wife (once his true love, before marriage). The presence of a child generates an unexpected solidarity between the two rival women.

A POEM BY PARANAR FROM THE SHORT SELECTION

(KURUNTOKAI 128)

You're like a wingless old heron on the waves of the eastern sea trying to fish for minnows on the shores of the western sea, near Tondi, where the Chera king drives his fine chariot. All you can think about, my heart, is that distant woman, utterly beyond reach. You're in pain, or rather: pain is who you are.

A POEM BY EYINANTAIMAKAN ILANKIRANAR FROM EXCELLENT LANDSCAPES (NARRIṆAI 308)

She heard the bustle of leaving.

Cold tears came to her eyes, dark with mascara,

like dew on flowers. When I called her, she came, 
shyly, reluctant, very slowly. She didn't ask me anything, or try to stop me, but like a finely painted doll smudged, coming unstuck, her fragrant hair glistening, she was shaken, lost in thought, and then she sank onto my chest, and my heart, still thinking about money, saw it and, like an unbaked clay pot drenched by rain, ${ }^{1}$ took her in and was happy.

A POEM BY CHAKALASANAR FROM FOUR HUNDRED IN THE INNER MODE (AKANĀÑŪ

Perfect hands

like petals enfolding

pollen-soaked filaments of lotus in the ancient otter pond,

mouth red as coral that

murmurs sweet wordless words

that make you smile,

gold bracelets that everyone envies ...

It was just our son

driving his toy chariot in the street,

alone. She saw him and,

teeth flashing, thinking no one

was watching, drew near,

took him between her young breasts heavy

with gold. "Come, my life," she said,

very happy. She'd noticed

the resemblance.

I saw her standing there. I did not

move away. "Why so confused,

young lady?" I said. "You, too,

are this one's mother." Quickly

I came and embraced her.

Like lovers taken by surprise, she looked down,

scraped the ground with her toe,

ashamed. That is how I saw her-and,

husband,

even I could have loved her then, you know?

She's like the distant goddess in the sky,

perhaps rightly compared

to your son's mother. 


\section{Jennifer Clare (Near Reader)}

When we read these beautiful translations of a few early Tamil poems, we are confronted with the most fundamental questions shaping what it means to be a sensitive reader of these traditions. On the one hand, Shulman's wielding of language, from vocabulary to syntax to rhythm, has produced poems that seize us with their exquisite beauty, love poems of the highest order. On the other hand, references throughout the poems, as well as their placement in this volume, remind us that these verses draw on conventions unfamiliar to most of us. As poems deeply embedded in a distant time and place, any interpretation that ignores these conventions seems deprived and wanting. Furthermore, these poems are of course translations from Tamil to English, with the full sense of loss and absence present in that word. How do we sensitively read poetry that speaks to us so intimately and also suggests such impenetrable distance? What is our relationship to these verses and the traditions-ancient, modern, Tamil, English, among many others-that inform them? There is, of course, no one answer to these questions, but the Tamil poems themselves offer models for thinking about our relationship to these verses in terms of the paradox inherent in relationship more generally, and the displacement that haunts all experiences of emotional connection. The models of relationship at work in the Tamil poems enrich and enliven our understanding of not only these individual verses, but also the experience-joyful, maddening, transformative-of deeply reading them.

At first glance, these poems seem to be about a very different kind of relationship than the one between a reader and a text. These are love poems, identified as interior (akam) by the Tamil poetic tradition, in which a fixed set of characters react to and comment on a series of highly codified stages of romantic love between an anonymous hero and heroine. The resulting vignettes, expressed in direct speech to an imagined addressee, share concerns with love poetry throughout South Asia and beyond: the joys and sufferings that come with navigating the emotional terrain of premarital and marital love.

Paranar's poem from The Short Selection (Kuruntokai 128) centers on one common conventional scenario: the hero berates his heart for yearning for a distant woman. Here, as in all akam poems, human relationship is the subject of the short verse. What primarily strikes the reader of this poem, however, is not the description of the relationship itself, but the way in which relationship structures the choice of literary figures for expressing this scenario. Specifically, in this poem, the relationship becomes visible through the figures of simile and identification. In the simile, the hero's heart is likened to a grounded old heron, looking for prey in the wrong place. Lost, flightless, pathetic-the specificity of the image of this feeble being draws us into a vivid, imagined landscape that generates a variety of complementary and contradictory feelings ranging from compassion 
to disgust to humor. On its own, this opening image creates a complex emotional palette that colors the questions that quickly follow: How did the bird become so lost? What is the Chera king doing here? These questions stay with us, evocative and open ended.

As the first part of an extended simile, this image of the frail and aged heron does not stand alone; it has an intimate connection to the second part of the poem, in which the hero berates his heart for dwelling on his distant beloved. By the end of the poem, the two-heron and heart-are entwined in our minds; one can no longer think of one without the other.

What is before us is a figure of identification, not just a simile, and the intensity of the identification denies the individual characteristics of heron and heart. Our interpretive work is to understand how this identification happens, and ultimately, to answer the question: how is the heart no different from the heron? However, like similes do, the literary figure of identification makes for an excess that it cannot erase; heart and heron may be the same, but they are also distinct, inevitably separate. The tension inherent in the figures of simile and identification-what is the same? what is different?-introduces an ambiguity in how we understand the relationship between heron and heart that is central to our reading of this poem.

This may all seem like much ado about literary figuration, but in fact the tension that structures these figures-between sameness and difference, union and separation-enacts the tension at the heart of the relationship depicted by the poem, that is, between the hero and his beloved. The experience of union leaves our hero intimately entwined with his lover, his heart and body no longer distinct from hers. At the same time, this union is haunted by the separation inherent in any relationship-how can we ever completely abandon the self (body, mind, heart) that distinguishes us from others? The literary figures of simile and identification are apt choices to express the paradox of relationship at the heart of this type of poetry.

So far the use of literary figures in the Tamil poems resonates with the use of simile and identification in love poetry throughout the world, especially in poems that describe love in separation. When we look at the akam poems in the context of their poetic tradition, we deepen our understanding and appreciation of how relationship functions in these poems. The form of Tamil poems of the interior is shaped by the conventions of a signifying system that ties the emotional worlds of the protagonists - the "interior landscapes" - to the exterior landscapes of South India. These systematic conventions are so strong that the mere mention of natural components (such as plants and animals-in our case, the heron) or cultural aspects (such as music or artisanal professions) associated with each exterior landscape is enough to bring into play an entire interior world. Moreover, through these conventions, every individual poem is simultaneously infused with the similar experiences found in other poems of the akam corpus. 
This is certainly the case with Paranar's poem. Per the conventions, the exterior landscape of the seascape in which this poem is set is a signal that the second part of the poem explores an interior landscape of anxious waiting. The landscape of anxious waiting includes the emotions associated with the hero's leaving the heroine before marriage to pursue his education or his career, but with the intent to return as a more eligible husband. It is a scenario that the readers of Tamil akam poetry would have encountered many times before.

In this poem, however, the central image of this exterior landscape is not a crab or crocodile, creatures typical of the seashore by convention, but a heron, conventionally associated with the exterior landscape of the delta, that is linked, equally by convention, with the interior landscape of marital infidelity and constant jealousy. How are we to understand this apparent breach of convention? Is our hero an ambitious young man suffering to better himself for his beloved, or is he a regretful old cheat? Tamil commentators on this poem took this ambiguity as a problem to redress and provided two contradictory readings that depend on committing the poem to one external and interior landscape or the other.

However, committing to one reading or the other misses the richness of the ambiguity produced by this mixing of conventions. We can read the contradictory readings as explicitly informing each other; after all, the lovesick young man may one day be the cheating husband, and the exiled two-timer may experience anxious waiting as he waits for his wife to let him return. We can also read the break with conventions as a reminder that these poems are both deeply connected to the conventional system and independent of it. On the one hand, the poem's deep connections with other poems in the tradition generates an intertextual web of signification from which an individual verse cannot be extricated. At the same time the verse stands as a distinct utterance, both in its unique wielding of literary linguistic conventions, and in its living history, whether sung at a royal court, used as examples for medieval grammars, or included here in a volume of South Asian literature in modern English translation.

Again the poems offer a model for thinking about this paradox, in which the verse and the tradition are simultaneously inseparable and distinct. As a poem about a young hero and/or a cheating husband, Paranar's is a poem about displacement, that liminal state that suggests the participant's belonging to something, as well as his or her exile from that state. Displacement infuses the image that begins Paranar's poem. While the poem doesn't reveal the reasons for the lost heron's displacement from delta to seashore, the contrast between its location on the east and the fish on the west suggests its frustration and inability. The heron's pathos in exile is juxtaposed with a brief description of the Chera king, whose movement, in contrast to the heron's, suggests purpose and ability. This dense, highly evocative image quickly becomes an analogy for the displacement in the second part of the poem: that of the hero's heart. Like the heron, the hero's heart searches for something beyond reach. Like the heron, the hero's heart is stuck in a limbo 
of exile, separated both from the beloved as well as from the hero himself, whose second-person admonishment of his heart further alienates it in a double exile.

Displacement, at once transformative and revelatory, is central to the logic of the corpus to which this poem belongs. For the protagonists of these poems, the experiences of love they navigate are closely bound up with separation from each other. The reasons for this separation vary from the hero's leaving the heroine to accumulate wealth, or to serve a king, to his spending time at the homes of beautiful courtesans. Many times, the reason for the separation remains unexpressed in the poem, but nonetheless it provides the contours for the complex emotions experienced by all the characters affected by the love dramas. As such, these characters themselves exist, like the heron and the heart of Paranar's poem, in a perpetual state of in-between, in which they are neither wholly united with their loved ones, nor wholly absent, as their inner worlds are consumed by the yearning, frustration, and occasional hope that are part and parcel of the experience of separation.

Just as the lovers exist in a liminal state between union and separation, the poems also mediate between two worlds: that of the interior lives of the protagonists, in whose voices the poems are set, and the exterior landscape of the seashore. The relationship between the interior and exterior landscape is both iconic-the exterior landscape occasionally, but not always, provides the location for the love scenes - and symbolic, providing a language for exploring the complexity of human emotion. Regardless of how strictly we apply the symbolic vocabulary, we as readers nonetheless find ourselves suspended between two landscapesexterior and interior - that are, like the separated protagonists of the poem, simultaneously interdependent and distinct, simultaneously particular and generic.

Returning to the identification of the heron and the heart, we encounter another profound dislocation. As parts of a simile, hero and heart are neither discretely intact, nor wholly consumed by the figurative union. As sensitive readers of the simile, we too are always in between. The resulting interpretive ambiguity can never be resolved or erased; rather, it is in acknowledging the disorientation of displacement, at the level of character, landscape, or figure of speech, that we understand the nature of relationship as expressed by the akam poems.

If Paranar's poem enacts relationship through the use of simile and the poetics of the interior landscape, the second poem, by Eyinantaimakan Ilankiranar, gives us a rich narrative of the transformations that come to be in displacement. The poem begins with "the bustle of leaving," that threshold moment of departure in between presence and separation. The next few lines depict the heroine's physical response to this moment. The changes brought about to her body and mind are both transformative and revelatory: she is changed by her knowledge of the new emotional landscape she has already begun to inhabit, but the bleakness of this landscape (identified as wasteland by the tradition) is offset by the luminosity of her love that this moment reveals. She becomes "smudged," "unstuck," "shaken," as the lines around her blur and who she is becomes unrecognizable. Similarly, 
the hero, whose heart was "still thinking of money" is transformed by the power of this love, and becomes undone, melting "like an unbaked clay pot drenched in rain," a state that allows him to take her in and be happy.

This is the powerful beauty of the liminal state of relationship expressed by the akam poems. We as readers, like the lovers, feel the intensity of this moment precisely because of the imminent separation: the undoing of the hero's heart that is the source of such poignant joy in this poem will condemn him to an even more awful exile. This experience is not narrated here but, as we know from the hero of Paranar's poem, it will be one of great pain. It will be a pain haunted by the fact that this suffering is proof of the hero's capacity for great love, for the kind of love that unmoors a heart from itself and leaves it forever transformed. And we too, as sensitive readers, might feel the intensity of this moment, like the lovers, for the lovers, finding our own hearts unmoored and even forever transformed.

The final poem by Chakalasanar presents us with yet another model for how the complexity of human relationship helps us think about sensitive reading. The central theme here is deceit: a wife confronts her two-timing husband about the woman with whom he has been cheating. This is no simple spousal scolding or sulking, but a display of deceit's power to twist, transform, reveal, and even create. But I'm getting ahead of myself for readers new to the poem, who may not recognize the scope of deception on first reading. The poem begins, after all, with a charming portrait of an intimate encounter between a young boy playing in the street and an unidentified woman, who recognizes something in the boy that compels her to embrace him. Unbeknownst to her, this private moment is witnessed by the boy's mother, who interrupts the couple, alleviating any possible embarrassment by assuring the lovely young stranger that both women have a right to the boy's love.

All seems well between the two women, if a bit awkward, united in their love for a healthy little boy. But the poem then shifts to reveal the deceit that underlies the entire verse. What appears to be a woman's story about an exhibition of maternal warmth by a lovely stranger turns out to be a revelation of her husband's adultery, as the boy's mother informs her husband, by means of the story of her encounter with the lovely interloper, that she now knows all about his lover. As her speech comes to an end, we realize, along with the faithless husband, that we too have been subjected to a sleight of hand, in which what appeared simple and innocent is in fact full of deceptions.

In fact, deception has structured the entire poem, beginning with the ambiguity of the opening description. Metaphors that appear to describe the beauty of a woman-her body, her sweet innocence, her jewelry objects of envy-in fact refer to a child, whose role in the poem is not yet clear. A strange woman clutches to her breast a boy who is not her own, because he reminds her of another man and his chariot who is no longer there. The boy's mother embraces the female stranger and comforts this woman who has stolen her husband, both in silent 
acknowledgment of the deception that binds them together. Once we become aware of the deception that underlies the verse, these interactions demand a different reading.

Throughout the poem, the verse harnesses deception to reveal and explore truths of human relationship. These truths include, of course, the awareness of the affair, but they are more than that. Deception reveals the singular status of wife and mother, singular both in her incomparability and in her loneliness. Deception allows for a complex and unexpected intimacy between two women who love someone whose heart and body does not belong to them. Deception allows for the wife to play with her husband's feelings, evoking the beauty and sweet character of his lover while simultaneously contrasting the shame and barrenness that accompany the "other woman" with the goddess at home that he has neglected. Deception establishes the truths of their fractured marriage, but also reveals the potential for closeness between them as parents who share a beautiful child.

Of the three selected poems, this one requires the most careful attention, especially for readers unfamiliar with the tradition. Without sensitive reading, we might be deceived by the innocence of the interaction on the street, or, more likely, confused about the relationship between the characters. However, this disorientation is not particular to this poem or to this subject matter. Sensitive reading requires that we acknowledge the deception that lies between us and all language. Surely, context helps, just as our understanding of this poem becomes deeper once we situate the characters and subject matter. As in the earlier verses, the poetics of interior landscape provide interpretive guideposts in this poem. The reference to the lotus growing in the otter pond, for instance, situates this poem in the emotional world of married life, and thus helps identify the characters within that world. Even after identifying guideposts, however, we are never sure of where we stand, and it is in this ambiguity, this contradiction, this inability to be paraphrased, that truth lies.

\author{
THE UNBAKED CLAY POT IN POURING RAIN: \\ READING SANGAM POETRY TODAY \\ R. Cheran (Far Reader) \\ In Canada, \\ There is a body of water unknown to Tamils. \\ It is called: \\ Red earth and pouring rain. \\ R. CHERAN, THINAI MAYAKKAM
}

A few days after I finished writing the one hundredth poem for my new collection in Tamil, quoted in the epigraph, I received this selection of a few translated Sangam poems from the editors of this volume. ${ }^{2}$ I was still rereading some of 
my new poems at the time and wondering whether a few minor changes, such as reordering individual poems or adding spaces between stanzas, were warranted. Then I began reading David Shulman's translations. His selections included shorter poems in the akam or inner mode from The Short Collection (Kuruntokai), Excellent Landscapes (Narrinai), and Four Hundred in the Inner Mode (Akanānuūru) collections, as well as an entire decad from the Collection of Five Hundred Poems (Ainkurunūūu), Kapilar's “Ten on the Wild Boar," which was, as Shulman says in his note, "meant to be read as a unit, the individual variations adding up to a powerful whole."

It was a sweet surprise for me that Shulman included both Kapilar and Paranar in his selection. These are two of the greatest and perhaps most famous Sangam poets, and I adore both of them. As I read these poems again in Tamil and in Shulman's English translation together with my new poems, I was struck by the magical continuity of metaphors, metonymy, and the modes of poetic contemplation in Tamil literature across millennia. This perhaps is in contrast to a tendency in contemporary Tamil poetry to eschew the gentle musicality and metaphors of older poetry. This current tendency, as I have noted elsewhere, often prefers to rely on everyday speech, prosaic discourse, and events that can even be characterized as "anti-poetry," as inspired by Nicanor Parra. ${ }^{3}$ However, in contemporary Tamil poetry the structures and tone of the Sangam poems still appear occasionally. Whether it is ingrained or intentional is a different question altogether.

I am one of the thousands of witnesses and victims of the genocidal war in Sri Lanka, which ended on May 19, 2009. It may not be an exaggeration to note that after the Sangam period, this was the first time Tamils were engaged in a large-scale war that lasted for thirty years. The Liberation Tigers of Tamil Eelam (LTTE), widely known as the Tigers, were at the forefront of the war on the Tamil side. While fighting for a separate state for Tamils in Sri Lanka, the Tigers also drastically changed contemporary Tamil cultural and historic imagery and rituals to reflect certain Sangam era values and practices. They introduced burial instead of cremation for their war dead. Burial sites became "places where great heroes sleep," and the Sangam practice of erecting memorial stones for the dead warriors was reintroduced. Several songs linking the Sangam and the contemporary periods were composed and sung by popular Tamil Nadu artists, and these circulated widely. Prabhakaran, the leader of the LTTE, was hailed as a "Warrior King" in poetry and songs. In one popular song celebrating the birth of Prabhakaran, the poet says:

Sing, the dawn has bloomed;

Dance, the Sangam era has arrived. ${ }^{4}$

Inspired by Shulman's translations, what I intend to do in this essay is to reflect on Sangam poems and modern Tamil poems that speak of war. This will not be 
an exhaustive survey of war and poetry in either period. Rather, I will attempt to relate my own poetic self and poetics to some examples of classical and modern war poetry in Tamil.

Among the numerous powerful and evocative images from Sangam poetry, the mingling of "red earth and pouring rain" is well known, and in a sense, stands as an apt symbol for this early Tamil poetry's visceral linkages between nature, landscapes, and love in all its varieties, licit, illicit, stolen, and many others:

What could my mother be

to yours? what kin is my father

to yours anyway? And how

did you and I meet ever?

But in love

our hearts have mingled

like red earth and pouring rain. ${ }^{5}$

The poet is now named after his famous line. His name means "the one who belongs to the mingled red earth and pouring rain." What he emphasizes in his subtle and poetic way is the possibility and reality of two people falling in love irrespective of or ignoring the kind of divisions such as caste, landscape, region, economic status, and so on.

Another poem by poet Kaniyan Pungudranar in Four Hundred in the Public Mode (Puranānūuru) is equally evocative and is also widely quoted. Amid this century of "public" (puram) poems that extoll battlefields, bravery, and valor, this poem stands alone: it is a calmly eloquent verse that says, "Every town our hometown, / every man a kinsman." "This line and the poem itself have often been cited as an expression of Tamil cosmopolitanism and migratory attitude of Tamils in an ancient context, but it became especially vivid during and after the thirty years of civil war in Sri Lanka.

Shulman's translation from Excellent Landscapes (308) takes us to another powerful earth and rain metaphor-not in the context of love and union, but to the moment of separation, anguish, and the quintessential dilemma of whether to leave behind a beloved because of circumstances beyond one's control:

She heard the bustle of leaving.

Cold tears came to her eyes, dark with mascara,

like dew on flowers. When I called her, she came,

shyly, reluctant, very slowly. She didn't ask me

anything, or try to stop me, but like a finely painted doll

smudged, coming unstuck, her fragrant hair glistening,

she was shaken, lost in thought, and then she sank

onto my chest, and my heart, still thinking about money, saw it and, like an unbaked clay pot drenched by rain,

took her in and was happy. 
The unbaked clay pot dissolving in pouring rain is in stark contrast to the previous poem of the mingling of rain and red earth creating a union across divisions. The landscape simultaneously symbolizes both union and separation.

Prompted by reading Shulman's translations, I began rereading other Sangam poems in my own context of exile, war, displacement, and modern Tamil poetry. The decades of war in Sri Lanka have produced a huge corpus of modern Tamil poetry. In my reading, I was looking for instances of communities in exile, of mass displacement due to war, of deep sufferings, and of the consequent individual and collective trauma. Aside from the poem attributed to Pari's daughters, lamenting the loss of their father and their home in the Parampu hills, there are not very many poems about defeated people leaving their land. ${ }^{7}$ Burning of enemy villages, destruction of paddy fields, and looting are more commonly depicted as heroic acts befitting powerful kings. For example:

You march into the alien territories and play havoc on their guarded groves;

You set vast paddy fields on fire, which are ignorant of losing their uberty.

By your invasion, fertile plains turn into woods;

$\ldots$ the places where villages flourished

Are now scenes of great ruin. ${ }^{8}$

In a sense it was not surprising. Tamil kings and chieftains commissioned the compilation of poems into anthologies. The relationship between poets and herokings was mostly symbiotic. There are poems providing good counsel to the kings and in a few cases admonishing the kings for their moral failures. In one such instance, a certain Chola king, victorious in his battle against his enemy, imprisons that enemy's children along with others and brings them to his country only to kill them cruelly. In a public place, where hundreds of people have gathered, he buries them alive, leaving only their heads above the ground, and then has elephants trample them under foot. Coming to know about this imminent inhumane action, the poet Kovoor Kilar rushes to the site. Here are his wise words of counsel:

You come from the line of a Chola king

who gave his flesh

for a pigeon in danger,

and for others besides,

and these children also come

from a line of kings

who in their cool shade

share all they have

lest poets,

those tillers of nothing

but wisdom,

should suffer hardships. 
Look at these children,

the crowns of their heads are still soft.

As they watch the elephants

they even forget to cry,

stare dumbstruck at the crowd

in some new terror

of things unknown.

Now that you've heard me out,

do what you will. ${ }^{9}$

It is not surprising to find many poems depicting the horrendous suffering of ordinary people in war and mass displacement. The uneven nature of economic development in various regions and poetic landscapes always exacerbates suffering and loss. My rereading of Sangam poems "from below" pointed above all to certain absences and silences.

I will now return to the poem in the epigraph at the beginning of this essay and to my two new anthologies that are all largely centered on sea, rivers, and lakes, and focus on exile, mass displacement, genocide, and trauma. The first anthology is entitled Tinai mayakkam allatu neñcọ̄u kilartal ("Blurred Tịais or excited and extended conversations with the heart"). The one hundred short poems included in this collection are close to Sangam poems in tone and style. They are partly autobiographical, partly historical, and partly metaphors in search of a moral compass that lies outside the traditions of faith and religion and can be adequate to the context of war and the context subsequent to war.

My second anthology, Añar, consists of several elegies for my friends who disappeared or were killed in the war, and fellow poets and writers who passed away or committed suicide in the years that followed. ${ }^{10}$ After more than thirty years of writing war poetry, the elegies collected in this anthology now seem to me to be some of my best. The word añar in Tamil connotes irreparable grief, continuous grief, mental wounds, as well as individual and collective trauma. There are several references in Sangam poetry describing añar.

Those poems are also deeply embedded in the violence that spanned the past forty years in Sri Lanka, during both the war and its aftermath. The landscapes and mindscapes were scarred, tortured, and mutilated. They have literally become "minescapes"-lands littered with thousands of land mines and unexploded ordinances (UEOs).

The confusion and intermingling of the classical Sangam landscapes (tinai) in the context of war, displacement, and separation of people and families, eternal waiting, and searching for people who have disappeared have all added extra dimensions to Tamil poetry composed after the Sangam period. One such addition, as I have noted in an essay on theorizing Tamil diasporicity, is a possibility 
of conceptualizing exile, mass displacement, and asylum as a new land/mindscape (tinai). ${ }^{11}$ The experiences and trauma of forced migration, Tamil diasporic life with its complexities of multiple belongings and deterritorialized landscapes and mindscapes have been a painful yet powerful source for a new Tamil literature. It is possible to conceptualize this as a new tinai.

The concepts of landscape (tinai) and theme (turai) in classical Tamil poetry are an important part of our intellectual and literary tradition. They are unique in their creative blending of cultural, economic, ecological, musical, emotional, and poetic attributes. Tinai can be used simultaneously as a taxonomical tool for literary criticism and to encapsulate a Tamil eco-poetics of the human-nature relationship while equally expanding our understanding of Tamil-ness and Tamil identities and their relations to landscapes, spaces, and memory. As several Tamil poets in the diaspora have articulated, there is now a transnational Tamil poetics at work. This poetics and its social, political, and cultural contexts become crucial in rearticulating Tamil identity. Memory and memorialization, heritage and politics, simultaneously belonging to more than one nation and history are currently the major preoccupations of Tamil transnationalism. As Amrit Lal says, in the title of his review of the book In Our Translated World, "Today's Sangam explores grief, trauma, and exile." ${ }^{12}$ However, Tamil transnationalism is not free from its old nationalist moorings. The continuation of casteism among some sections of the second and third generation Tamils is another aspect that cannot be missed. A good example comes from many online postings of young Tamils in Germany and Switzerland. They are using a white dot in their Instagram postings to indicate that they are Vellala Tamils. They are proud of their heritage, and as one of the parents said, "we tell them all about our heritage, and they can choose what aspects of our tradition and culture they prefer to maintain and articulate."13

The Sangam metaphor of red earth and pouring rain has immortalized love above all human divisions. This is perhaps the best that Tamil has contributed to human civilization. The unbaked clay pot dissolves and creates a messy, muddy body of water. In Canada, as the poem I quoted in the beginning testifies, red earth and pouring rain is the only body of water that no Tamils, Tamil-Canadians, or Canadian Tamils would go to.

How a new tinai in the diaspora shapes and captures the nuances of transnational Tamil identities, poetics, and politics is a very pertinent question. But that is for another occasion. 